\title{
Mortality caused by experimental infection with the yeast Candida haemulonii in the adults of Ornithodoros moubata (Acarina: Argasidae)
}

\author{
Gabriela Loosová, Libor Jindrák and Petr Kopáček
}

Institute of Parasitology, Academy of Sciences of the Czech Republic and Faculty of Biological Sciences, University of South Bohemia, Branišovská 31, 37005 České Budějovice, Czech Republic

Key words: Candida haemulonii, soft ticks, pathogenic fungi

\begin{abstract}
A relatively high rate of mortality among engorged females of Ornithodoros moubata (Murray, 1877) was observed in our laboratory colony. The general aim of the study was to identify the causative agent responsible for this mortality. The diagnostic tests were performed by Yeast Identification Service (CBS-Delft, Netherlands) and the pathogen was identified as the yeast Candida haemulonii (van Uden et Kolipinski, 1962) Meyer et Yarrovi, 1978. The artificial infection study was performed by intrahaemocoelic inoculation of yeast suspension, resulting in a mortality of $37 \%$. The maximum mortality of ticks infected per os by contaminated blood meal was $13 \%$. Re-isolated yeast cells from haemolymph of dead and paralysed ticks were apparently identical with primary yeast cells, without loosing reproductive abilities. An occasional formation of elongated chains of yeast cells (pseudomycelium) was recorded. The majority of ticks infected in both experiments mentioned above survived and displayed no evident symptoms of the infection. The presence of yeast cells in the haemolymph of surviving ticks was not detected. The in vitro phagocytosis assay performed with FITC-labelled yeast cells showed that about $4 \%$ of tick haemocytes were phagocytically active against the pathogenic yeast cells. Thus phagocytosis seems to be a potent defence reaction against spreading and multiplying of the yeast $C$. haemulonii within the tick haemocoel.
\end{abstract}

Ticks, blood-sucking arthropods, are important ectoparasites of humans and animals. They are responsible for severe economic losses through the direct effects of blood sucking on livestock, and indirectly as vectors of pathogens. Feeding by large numbers of ticks causes reduction in live weight gain and anaemia among domestic animals. However, the major losses caused by ticks are due to their ability to transmit protozoan, rickettsial and viral diseases (Jongejan and Uilenberg 1994). The soft tick Ornithodoros moubata (Murray, 1877 ) is one of the most serious vectors of pathogens that attack human health in tropical and subtropical areas. It is the main vector of African tick-borne relapsing fever, caused by spirochaetes Borrelia duttoni.

One approach that may limit tick populations is the use of organisms such as pathogens, parasitoids and predators. These alternative biological control methods may avoid some of the problems associated with chemical acaricides (Samish and Glazer 1991). In spite of their importance, we still know very little about the application of biological control agents.

The present paper describes isolation of a fungal agent responsible for high mortality among engorged females of O. moubata in our laboratory colony. An additional aim was to determine the nature of the infection and discover the possible route of pathogen transmission.

\section{MATERIALS AND METHODS}

Ticks. Adult $O$. moubata were kept separately in polyethylene cages in a room maintained at $25-27^{\circ} \mathrm{C}$ and $80-90 \%$ relative humidity. The ticks were fed artificially through a Parafilm ${ }^{\mathrm{TM}}$ membrane on pre-warmed $\left(40^{\circ} \mathrm{C}\right)$ whole-citrated bovine blood until repletion. Excess blood was washed from fed ticks. Ticks remained on filter paper until coxal fluid excretion was completed and then maintained as described above.

Haemolymph collection and examination. Haemolymph samples were obtained from paralysed or dead adult tick females by piercing one of their legs with a sterile pair of scissors. The outflowing haemolymph was collected onto a sterile cover glass and examined with a light microscope for yeasts.

Cultivation of yeast cells. The yeast cells from the haemolymph were cultivated on Sabouraud dextrose agar dishes (SDA) with addition of antibiotic $(200 \mu \mathrm{g} / \mathrm{ml}$ ampicillin 1.0 ; Biotika) at $25^{\circ} \mathrm{C}$ for 14 days.

Identification of yeast cells. The pure strain was obtained by a routine slicing method. This strain on the SDA was submitted to the Yeast Identification Service (CBS-Delft, Netherlands) for further identification.

Artificial infection by yeast cells. Yeast cells were transferred by a sterile loop into $1 \mathrm{ml}$ of sterile phosphate buffered saline (PBS) and stirred well. The suspension of yeast cells was adjusted to a final concentration $2.8 \times 10^{9} / \mathrm{ml}$ using a Bürker counting chamber. A group of 125 adult female ticks was injected through the dorsolateral cuticle with $15 \mu \mathrm{l}$

Address for correspondence: P. Kopáček, Institute of Parasitology, Academy of Sciences of the Czech Republic, Branišovská 31 , 370 05 České Budějovice, Czech Republic. Phone: ++ 42038777 2207; Fax: ++420 38 5300388; E-mail: kopajz@paru.cas.cz 
of yeast suspension $\left(4.2 \times 10^{7}\right.$ yeast cells). The injection was performed using 1-ml disposable syringes mounted on a microapplicator. The control group of 125 adult females was inoculated with sterile PBS. The ticks were placed into sterile Petri dishes and kept at $25^{\circ} \mathrm{C}$. Mortality was recorded daily for 33 days.

Infection per os. One $\mathrm{ml}$ of the yeast suspension with concentrations: $1.5 \times 10^{7} / \mathrm{ml} ; 3.7 \times 10^{9} / \mathrm{ml} ; 1.0 \times 10^{10} / \mathrm{ml}$ was added to $100 \mathrm{ml}$ tick blood meal. For each feeding experiment 25 adult females were used. The control group of 125 adult females was fed with non-infected blood meal.

Preparation of fluorescent particles. Fresh C. haemulonii cells were labelled with fluorescein isothiocyanate (FITC) according to the method described for the baker's yeast by Wiesner et al. (1998). Briefly, C. haemulonii were inoculated into $200 \mathrm{ml}$ autoclaved culture medium (1\% yeast extract, $2 \% \mathrm{D}(+)$ glucose monohydrate and $0.05 \%$ peptone) and incubated at $37^{\circ} \mathrm{C}$ overnight. Cells were harvested from 1$\mathrm{ml}$ aliquots by centrifugation $(200 \times \mathrm{g}, 10 \mathrm{~min})$ and washed three times with $1 \mathrm{ml}$ of sterile PBS. The last washing was performed in distilled water. The yeast cells were then resuspended in $1 \mathrm{ml}$ of sterile $0.2 \mathrm{M}$ sodium carbonatebicarbonate buffer, $\mathrm{pH} 9.4$ to which $1 \mathrm{mg}$ of FITC was added. The cell suspension was incubated on a shaker for $30 \mathrm{~min}$ (room temperature, darkness). The unbound FITC was thoroughly washed out with PBS (four washes) and once with distilled water. The pellet from the final wash was resuspended in $1 \mathrm{ml}$ of Grace's insect medium (GIM, Serva). FITClabelled yeast cells were counted in a Bürker counting chamber. The density of yeast cells was adjusted to $1 \times 10^{8}$ cells $/ \mathrm{ml}$ with GIM and stored in aliquots at $-20^{\circ} \mathrm{C}$.

Phagocytosis assay. The phagocytic activity of haemocytes was determined using the in vitro microscopic fluorescence assay described by Rohloff et al. (1994). The assay was performed using 4-well chamber slides ${ }^{\mathrm{TM}}$ (Nunc). Aliquots $(200 \mu \mathrm{l})$ of freshly collected haemolymph with predetermined concentration of haemocytes were pipetted into each testing well and haemocytes were allowed to settle and attach for $30 \mathrm{~min}$ at room temperature. Then, $100 \mu \mathrm{l}$ aliquots of fluorescent yeast suspension were added dropwise to each well. Concentration of yeast cells in the suspension was preadjusted to assure the optimum ratio of haemocytes : yeast cells to be roughly $1: 10$. The chamber slides were incubated at $31^{\circ} \mathrm{C}$ in the dark for 2 hours. Then, $200 \mu \mathrm{l}$ of culture medium from each well was replaced by the same volume of trypan blue solution $(4 \mathrm{mg} / \mathrm{ml}$ dissolved in GIM, filtered). After $20 \mathrm{~min}$, quenching of the yeast cells not ingested by haemocytes was completed. The procedure was stopped by rinsing the cell cultures three times with GIM. After the last washing step, the haemocyte nuclei were stained with $150 \mu \mathrm{l}$ DAPI-solution $\left(10^{-4} \mathrm{M} 4^{\prime}, 6^{\prime}\right.$-diamidino-2-phenylindole in 6.4 $\mathrm{mM} \mathrm{Na}_{2} \mathrm{HPO}_{4}, 3.6 \mathrm{mM} \mathrm{KH} \mathrm{PO}_{4}, \mathrm{pH}$ 7.2) for $20 \mathrm{~min}$. Then supernatant was removed and the monolayers were fixed with $4 \%$ formaldehyde in GIM. Phagocytic activity was determined as a percentage of phagocytically active haemocytes (containing at least one FITC-labelled yeast cell) out of total 600 haemocytes counted using a BX 60 Olympus fluorescence microscope.

Photography. All images were photographed using an Olympus PM 20 camera.

\section{RESULTS}

A relatively high rate of mortality among laboratory colony of $O$. moubata was caused by extreme paralysis that led to death. Microscopic examination of haemolymph from dead ticks revealed the presence of ellipsoidal budding yeast-like microorganisms.

The samples of these microorganisms were submitted to the specialised laboratory of Yeast Identification Service in Delft, Netherlands. After both, routine and extended determination procedures the pathogen was identified as Candida haemulonii (van Uden et Kolipinski, 1962) Meyer et Yarrovi, 1978, a species of the imperfect yeasts. This strain has been deposited in the collection of the Yeast Division of the Centraalbureau voor Schimmelcultures in Delft as No. G98-115.

Ticks, artificially infected by intrahaemocoelic inoculation of $15 \mu \mathrm{l}$ yeast suspension $\left(4.2 \times 10^{7}\right.$ cells $)$, displayed typical symptoms as described above. The growth of $C$. haemulonii within haemolymph of dead and paralysed ticks was apparently not suppressed. An occasional formation of elongated chains of yeast cells was recorded (Fig. 1). The artificial infection led to a total $37 \%$ mortality; $27 \%$ of the infected ticks died in 21 days and another $10 \%$ died in 22-33 days after inoculation (Fig. 2). The mortality within control group was $1.6 \%$, and it was attributed to damage caused to ticks during inoculation.

The mortality of ticks infected per os by contaminated blood meal was positively related to yeast cell concentration (Fig. 3). The maximum mortality recorded, achieved by $1.0 \times 10^{10}$ cells $/ \mathrm{ml}$, was $13 \%$. The mortality of $10 \%$ was obtained already after 14 days, while in the case of the lowest concentration $\left(1.5 \times 10^{7}\right.$ cells $/ \mathrm{ml}$ ) the mortality gradually reached $10 \%$ after 28 days. In the control experiment with non-infected blood meal, no mortality was recorded. The yeast cells of $C$. haemulonii were isolated directly from the haemolymph of dead and paralysed ticks. Re-isolated yeast cells were apparently identical with primary yeast cells, without loss of reproductive ability. Per os infection experiments with contaminated blood meal indicated that feeding was most likely the natural route of infection within our laboratory colony.

The majority of ticks infected in both experiments mentioned above survived and displayed no evident symptoms of the infection. The presence of yeast cells in the haemolymph of surviving ticks was not detected. Thus it seems that the resistant ticks possessed an efficient mechanism that made it possible to clear out the yeast cells from their haemolymph.

The in vitro phagocytosis assay performed with FITC-labelled yeast cells showed that about $4 \%$ of tick haemocytes were phagocytically active against the pathogenic yeast cells (Fig. 4). Thus phagocytosis seems to be a potent defence reaction against spreading and multiplying of the yeast $C$. haemulonii within the tick haemocoel. 


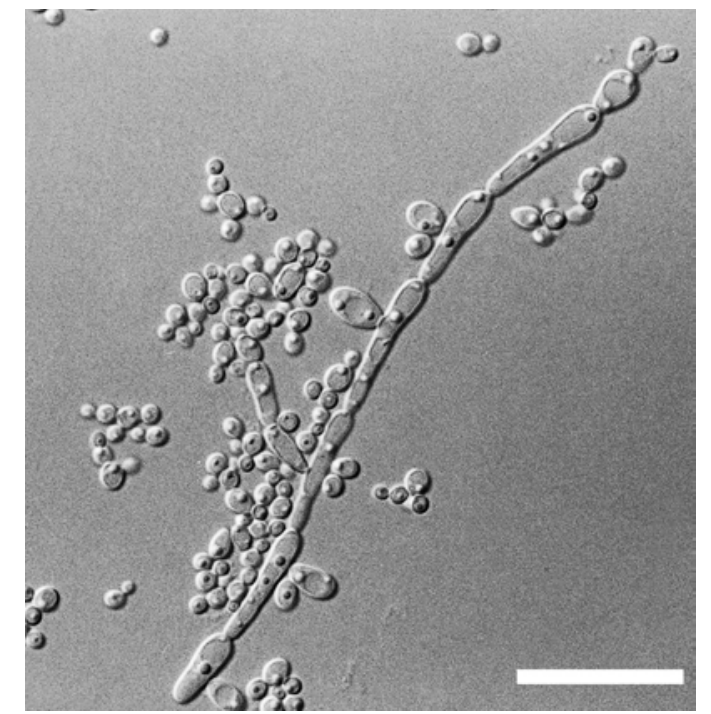

Fig. 1. Candida haemulonii (pseudomycelium), Nomarski differential interference contrast. Scale bar $=10 \mu \mathrm{m}$.

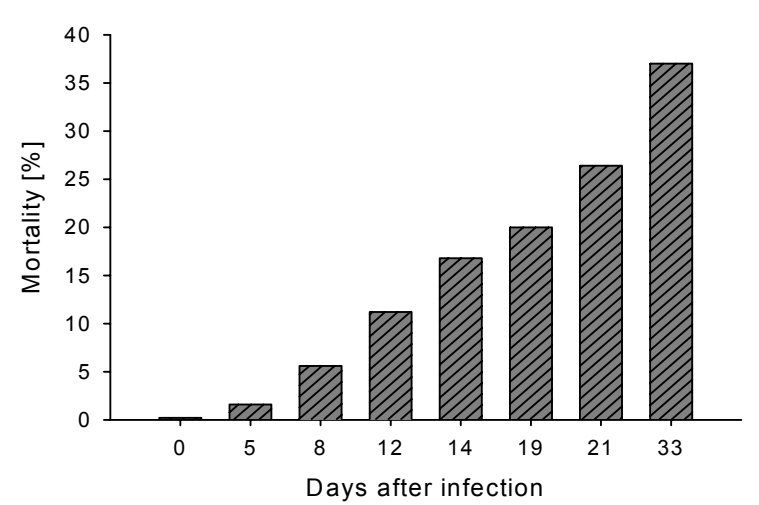

Fig. 2. Cumulative mortality of the adult females of Ornithodoros moubata caused by Candida haemulonii on various days after experimental intrahaemocoelic infection $\left(2.8 \times 10^{9}\right.$ cells $\left./ \mathrm{ml}\right)$.

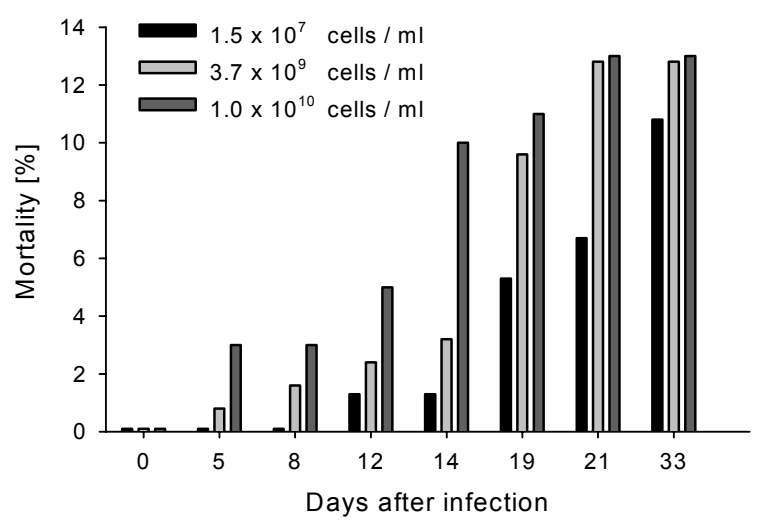

Fig. 3. Cumulative mortality of the adult females of Ornithodoros moubata caused by different doses of Candida haemulonii on various days after infection per os.

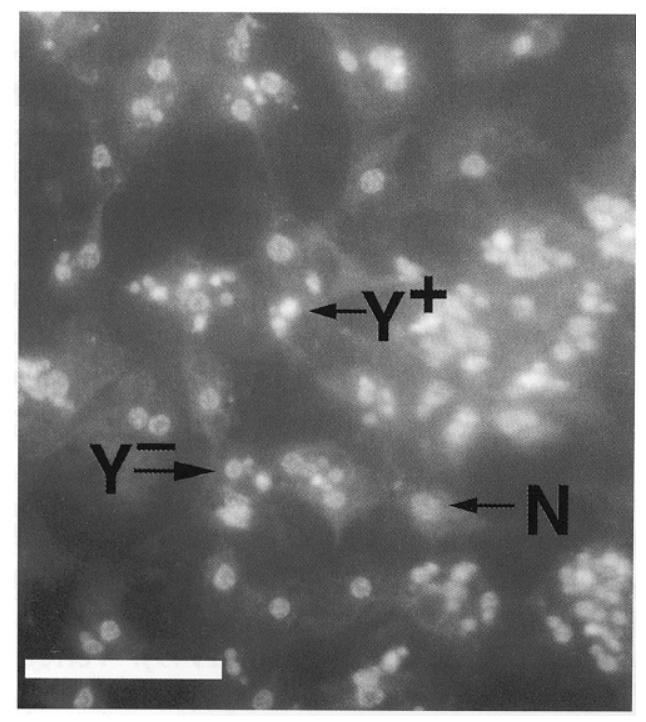

Fig. 4. Micrograph of Ornithodoros moubata haemocytes after phagocytosis of FITC-labelled yeast cells. Fluorescence. Ingested yeast cells retained their fluorescence after quenching with trypan blue. Non-ingested cells became dark. $\mathrm{N}$ - nucleus of haemocyte, stained by DAPI-solution; $\mathrm{Y}^{+}-$ingested yeast cell; $\mathrm{Y}^{-}$- non-ingested yeast cell. Scale bar $=20 \mu \mathrm{m}$.

\section{DISCUSSION}

Studies on naturally occurring pathogens of ticks have been done in an attempt to establish their importance in regulating natural tick populations (Mwangi et al. 1995). Except for the entomopathogenic fungi, little attention has been paid to the other microorganisms pathogenic for ticks.

Sidorov and Scherbakov (1973) reported viral infection in laboratory colonies of Ornithodoros moubata, O. pavlovskyi, O. lahorensis and Argas persicus. Virus-like particles caused ulcers in different body areas, particularly deformities of the mouthparts. A few species of bacteria have been reported to be pathogenic for ticks. Brown et al. (1970) noted an endemic disease among laboratory populations of the hard tick Dermacentor andersoni. The causative agent was isolated from these dead ticks and identified as the bacterium Proteus mirabilis. Four Gram-negative bacteria (Proteus sp., Klebsiella pneumoniae, Pseudomonas sp., P. mirabilis) and one Gram-positive bacterium (Staphylococcus sp.) were isolated from the laboratory colonies of the hard tick Boophilus decoloratus (Hendry and Rechav 1981).

Most organs of laboratory-bred O. moubata contain rickettsia-like microorganisms. Weyer (1953) succeeded in isolating Coxiella burnetii from digested host blood and coxal fluid of parenterally inoculated O. moubata. Multiplication of Rickettsia australis was observed in the haemolymph of the same tick species (Řeháček 1965). Reinhardt et al. (1972) recorded the presence of long rickettsia-like microorganisms in all examined organs of both sexes of $O$. moubata with the exception of spermioduct and the testicles. 
The entomopathogenic fungi play a major role in reducing natural populations of ticks. Natural infection of hard ticks by entomopathogenic fungi was recorded by Lipa (1971), Samšiňáková (1957), Samšiňáková et al. (1974) and Estrada-Peña et al. (1990). Many ixodid ticks were found to be infected with several species of fungi, belonging mostly to the group of Fungi Imperfecti (Aspergillus, Beauveria, Fusarium, Paecilomyces, Verticillium). Krylova (1972) isolated from the argasid tick Argas persicus the fungi of the genera Penicillium and Aspergillus.

The species of the genus Candida are not often reported as entomopathogens. Candida zeylanoides has been identified as a pathogen in Douglas-fir tussock moths, Orgyia pseudotsugata (Martignoni et al. 1969) and in Blatta orientalis (Rozoni 1949). Verrett et al. (1987) described a new Candida species to be a parasite of the American cockroach Periplaneta americana. El Said (1992) investigated yeast-like microorganisms associated with the sperm cells of the ixodid ticks Hyalomma marginatum, $H$. dromedarii and Amblyomma hebraeum. These microorganisms represented extracellular symbionts, produced by male and introduced in the genital system of the female through copulation. They occurred in the form of compact spherules and morulae that did not alter their shape and did not attach to the sperm cells. In contrast to this observation, Feldman-Muhsam and Havivi (1962) described microorganisms, that attached to a specific zone of the sperm cells in the spermatophores of the soft tick Ornithodoros tholozani.
Candida haemulonii was originally isolated from the gut of the bluestriped grunt fish Haemulon sciurus and to date has not been reported to be part of natural microbial flora of the soft tick O. moubata. Our experiments demonstrated the possible transmission of the pathogen via contaminated bovine blood meal. In order for the pathogen to kill susceptible ticks, it is apparently necessary for the yeast particles to overcome the intestinal barrier and penetrate into haemolymph. From the results presented in this paper it is obvious that isolated haemocytes are phagocytically active against yeast cells in vitro. The phagocytic activity of nonstimulated tick haemocytes against $C$. haemulonii was relatively high (4\%). For comparison, less than $1 \%$ of nonstimulated insect haemocytes (Galleria mellonella) were phagocytically active against cells of the yeast Saccharomyces cerevisiae (Wiesner et al. 1998). It remains an unresolved issue if the intestinal barrier and/or immune response within the haemocoel are compromised in the ticks susceptible to candidiasis. Further research is in progress about the mechanisms involved in tick defence against the pathogenic yeast $C$. haemulonii.

Acknowledgements. This work was supported by the grant 206/00/0266 to P.K. from the Grant Agency of the Czech Republic and by the project VS 96066 from Ministry of Education and Sports of the Czech Republic. The helpful comments of Dr. František Dusbábek and editorial work of Heidi Splittgerber during the manuscript preparation are highly appreciated.

\section{REFERENCES}

BROWN R.S., REICHELDERFER C.F., ANDERSON W.R 1970: An endemic disease among laboratory populations of Dermacentor andersoni. J. Invertebr. Pathol. 16: 142143.

EL SAID A. 1992: Ultrastructure of symbiont-like microorganisms associated with the sperm of ixodid ticks. J. Egypt. Soc. Parasitol. 22: 293-297.

ESTRADA-PEÑA A., GONZALEZ J., CASASOLAS A. 1990: The activity of Aspergillus ochraceus on replete females of Rhipicephalus sanguineus in natural and experimental conditions. Folia Parasitol. 37: 331-336.

FELDMAN-MUHSAM B., HAVIVI Z. 1962: A microorganism associated with sperm cells of Ornithodoros. Nature 17: 1095-1096.

HENDRY D.A., RECHAV Y. 1981: Acaricidal bacteria infecting laboratory colonies of the tick Boophilus decoloratus. J. Invertebr. Pathol. 38: 149-151.

JONGEJAN F., UILENBERG G., 1994: Ticks and control methods. Rev. Sci. Tech. 13: 1201-1226.

KRYLOVA V.N. 1972: Some problems in the study of fungal disease of the bed bugs Cimex lectularius and ticks Argas persicus. In: Mikrobiol. metody borby s ektoparazit. ptits, Ilim, Frunze, pp. 53-55. (In Russian.)
LIPA J.J. 1971: Microbial control of mites and ticks. In: H.D. Burges and N.W. Hussey (Eds.), Microbial Control of Insects and Mites, Academic Press, New York, pp. 357373.

MARTIGNONI M.E., IWAI P.J., WICKERHAM L.J. 1969: A candidiasis in larvae of the Douglas-fir tussock moth, Hemerocampa pseudotsugata. J. Invertebr. Pathol. 14: 108-110.

MWANGI E.N., KAAYA G.P., ESSUMAN S. 1995: Experimental infections of the tick Rhipicephalus appendiculatus with entomopathogenic fungi, Beauveria bassiana and Metarhizium anisopliae and natural infections of some ticks with bacteria and fungi. J. Afr. Zool. 109: 151-160.

REINHARDT CH., AESCHLIMANN A., HECKER H. 1972: Distribution of Rickettsia-like microorganisms in various organs of an Ornithodoros moubata laboratory strain (Ixodoidea, Argasidae) as revealed by electron microscopy. Z. Parasitenkd. 39: 201-209.

ROHLOFF L.H., WIESNER A., GÖTZ P. 1994: A fluorescence assay demonstrating stimulation of phagocytosis by haemolymph molecules of Galleria mellonella. J. Insect Physiol. 40: 1045-1049. 
ROZONI M.G. 1949: Fungi lievi ti formi isolate dalle oveteche di Periplaneta orientalis L. Mycopathologia 4: 333-341.

ŘEHÁČEK J. 1965: Development of animal viruses and rickettsiae in the ticks and mites. Annu. Rev. Entomol. 10: $1-24$.

SAMISH M., GLAZER I. 1991: Killing ticks with parasitic nematodes of insects. J. Invertebr. Pathol. 58: 281-282.

SAMISH M., ŘEHÁČEK J. 1999: Pathogens and predators of ticks and their potential in biological control. Annu. Rev. Entomol. 44: 159-182.

SAMŠIŇÁKOVÁ A. 1957: Beauveria globulifera as a parasite of the tick Ixodes ricinus L. Folia Zool. 6: 329330.

SAMŠIŇÁKOVÁ A., KÁLALOVÁ S., DANIEL M., DUSBÁBEK F., HONZÁKOVÁ E., ČERNÝ V. 1974: Entomogenous fungi associated with the tick Ixodes ricinus. Folia Parasitol. 21: 39-48.

Received 14 April 2000
SIDOROV V.E., SCHERBAKOV S.V. 1973: Mass epizootics among Alveonasus lahorensis Neumann ticks. Med. Parazitol. Parazit. Bolezni. 42: 47-51. (In Russian.)

VERRETT J.M., GREEN K.B., GAMBLE L.M., CROCHEN F.C. 1987: A hemocoelic Candida parasite of the American cockroach (Dictyoptera: Blattidae). J. Econ. Entomol. 80: $1205-1212$.

WEYER F. 1953: Die Beziehungen des Q-Fieber-Erregers (Rickettsia burnetii) zu Arthropoden. Z. Tropenmed. Parasitol. 4: 344-382.

WIESNER A., ROHLOFF L.H., WITTWER D., POHL U., van SAMBEEK J., KURTZ J., GÖTZ P. 1998: Phagocytosis by insect hemocytes in vitro. In: A. Wiesner, G.B. Dunphy, V.J. Marmaras, I. Morishima, M. Sugumaran and M. Yamakawa (Eds.), Techniques in Insect Immunology. SOS Publications, Fair Haven, pp. $11-20$.

Accepted 30 October 2000 